\author{
B.B. Kutum, G.N. Shaikhova \\ L.N. Gumilyov Eurasian National University, Nur-Sultan, Kazakhstan \\ (E-mail: kuttykadam@mail.ru)
}

\title{
Q-soliton solution for two-dimensional q-Toda lattice
}

\begin{abstract}
The Toda lattice is a non-linear evolution equation describing an infinite system of masses on a line that interacts through an exponential force. The paper analyzes the construction of soliton solution for the q-Toda lattice in the two-dimensional case. For this purpose, the equation of motion is taken and the transformation of the dependent variable is used to convert the nonlinear equation into a bilinear form, which is written as the Hirota polynomial. As one of the most effective methods for constructing multisoliton solutions of integrable nonlinear evolution equations, Hirota method is applicable to a wide class of equations, including nonlinear differential, nonlinear differential-difference equations. Using the Hirota method, the bilinear form was obtained for the two-dimensional q-Toda lattice on the basis of which the q-soliton solution was found. The dynamics of the q-soliton solution for two-dimensional q-Toda lattice is presented. Note that the soliton is conserved due to the equilibrium between the action of the nonlinear environment with dispersion. In addition, the soliton behaves like a particle: does not collapse when interacting with each other or other disturbances, while maintaining the structure and continues to move. This quality has the ability to use when transferring data or information over long distances with virtually no interference. In addition, the study of the Toda lattice and the application to it of different methods in different dimensions allows one to proceed to the understanding of such complex terms as matrix models that can be used to describe different physical systems.
\end{abstract}

Keywords: dispersion, soliton, Toda lattice, bilinear form, Hirota method.

\section{Introduction}

Waves described by different nonlinear differential equations, which consist of special pulses, have the property of preserving their original shape like stable particles. They are called solitary waves, single wave particles or solitons. Nonlinear lattices or lattices also contain solitons. When the energy is not very large, nonlinear lattices behave periodically, so stable pulses propagate in such nonlinear continuous systems. The fact of the existence of such lattices shows that there must be some non-linear lattice that allows strict periodic waves, and certain impulses will be stable. One such example is the Toda lattice equation. The Toda lattice is a non-linear evolution equation describing an infinite system of masses on a line that interacts through an exponential force. The Toda lattice is considered as a simple model of the nonlinear onedimensional crystal in solid state physics. It is defined by a lattice of particles with the interaction of the nearest neighbor, described by the equations of motion [1].

To find the exact solutions for nonlinear differential equations, a huge number of methods are used, such as the Backlund transform [2], the Hirota method [3], the inverse scattering transform method [4], and others. One of the most effective methods for constructing soliton solutions of integrable nonlinear evolution equations is the direct Hirota method, which can be found in [3]. This method is applicable to a wide class of equations, including nonlinear differential, nonlinear differential-difference equations [5-7]. The initial step in this method is to use the transformation of the dependent variable to convert nonlinear partial differential equation into a quadratic form, the so-called bilinear form. The main idea of the method is to write the bilinear form as a Hirota polynomial - D. This compact form is called Hirota's bilinear form. It should be noted that nonlinear partial differential or differential-difference equations can have not only Hirota bilinear forms but also trilinear or multilinear forms [8]. It is assumed that all fully integrable nonlinear partial differential equations or difference equations can be written in Hirota bilinear form. On another hand, for an equation that admits Hirota's bilinear form, the existence of $\mathrm{N}$-soliton solutions of any order is not guaranteed. The equations admitting Hirota's bilinear form and having N-soliton solutions are called integrable by Hirota [9].

In this paper, we present a two-dimensional q-Toda lattice. A one-dimensional case for this equation was studied in [10]. Using the Hirota bilinear method, we find the bilinear form for the twodimensional q-Toda lattice. Dispersion relation and the q-soliton solution are obtained by bilinear form for the two-dimensional q-Toda lattice. 


\section{Two-dimensional q-Toda lattice}

In the beginning, classical mechanics was studied specifically for one-dimensional lattices, where the particles forming them interact only with their nearest neighbors. If we restrict their consideration to homogeneous systems, then the mass of each particle is denoted by $m$, the displacement of the $n$-th particle $y_{n}$ and the interaction potential between neighboring particles is $\varphi\left(y_{(n+1)}-y_{n}\right)$. Then the equation of motion takes the following form

$$
m \frac{d^{2} y_{n}}{d t^{2}}=\varphi^{\prime}\left(y_{(n+1)}-y_{n}\right)-\varphi^{\prime}\left(y_{n}-y_{(n-1)}\right)(n=\ldots,-1,0,1,2 \ldots)
$$

where $\varphi^{\prime}$ derivative $\varphi$. Thus,

$$
f(r)=-\varphi^{\prime}(r)=-\frac{d \varphi(r)}{d r}
$$

$f(r)$ is a force which the spring acts, stretched by the value of $r_{n}$

$$
r_{n}=y_{n+1}-y_{n} \text { or } \quad r_{n}=y_{n}-y_{n-1}
$$

(3) - this is a relative displacement. When the force $f(r)$ is proportional to the displacement $r_{n}$ Hooke's law is satisfied. The Toda equation [10], describing the motion of the anharmonic lattice, has the form

$$
m \frac{d^{2} y_{n}}{d t^{2}}=a\left[e^{b r_{n}}-e^{-b r_{n}}\right]
$$

where $a, b$ and $m$ are real constants. Introducing the force of the $n$-th particle into the lattice, we obtain the following equation

$$
V_{n}=a\left[e^{b r_{n}}-e^{-b r_{n}}\right],
$$

as a rapidly decreasing function, equation (4) turns out to be

$$
\frac{d^{2}}{d t^{2}} \ln \left(1+V_{n}\right)=V_{(n+1)}+V_{(n-1)}-2 V_{n} .
$$

The two-dimensional q-Toda lattice has the following form

$$
\frac{d^{2}}{d x d t} \ln (1+V(x, y, t))=\Delta_{x}^{2} V(x, y, t)=V(x, q y, t)+V\left(x, \frac{y}{q}, t\right)-2 V(x, y, t) .
$$

Present the transformation of the dependent variable as

$$
V(x, y, t)=\frac{d^{2}}{d x d t} \ln (f(x, y, t))
$$

Substituting (8) into (7) and integrating the obtained expression twice, we get

$$
\frac{f_{x t}-f_{t} f_{x}}{f^{2}}=\frac{f(x, q y, t) f\left(x, \frac{y}{q}, t\right)}{f^{2}}-1
$$

Equation (9) can be rewritten in the Hirota bilinear form, namely in terms of the Hirota D-operator, as

$$
\left[D_{x} D_{t}-\left(e^{h y D_{y}}+e^{-h y D_{y}}-2\right)\right]\{f(x, y, t) \cdot f(x, y, t)\}=0,
$$

which follows from (9) by multiplying by $2 f^{2}(x, y, t)$, where we use the q-exponential identity [10]. For functions $f(y), g(y)$ the q-exponential unit [10] will be

$$
e^{h y D_{y}} f(y) g(y)=f(q y) g\left(\frac{y}{q}\right)=E_{q} f(y) E_{q}^{-1} g(y), y \in R .
$$

The last equation is satisfied if we have the usual relation between two quantum parameters $h$ and $q$ for $q=e^{h}$. To find the soliton solutions of the Toda lattice, we apply the expansion of perturbations around the formal perturbation parameter $\varepsilon$ in the form

$$
f(x, y, t)=1+\epsilon f^{(1)}(x, y, t)+\varepsilon^{2} f^{(2)}(x, y, t)+\cdots .
$$

Substituting (12) into (10) we obtain the equation

$$
\begin{gathered}
P(D)\{f(x, y, t) \cdot f(x, y, t)\}=P(D)\left[\{1 \cdot 1\}+\varepsilon\left\{1 \cdot f^{(1)}+f^{(1)} \cdot 1\right\}\right. \\
+\varepsilon^{2}\left\{1 \cdot f^{(2)}+f^{(2)} \cdot 1+f^{(1)} \cdot f^{(1)}\right\}+\varepsilon^{3}\left\{1 \cdot f^{(3)}+f^{(3)} \cdot 1+f^{(1)} \cdot f^{(2)}+f^{(2)} \cdot f^{(1)}\right\} \\
\left.+\varepsilon^{4}\left\{1 \cdot f^{(4)}+f^{(4)} \cdot 1+f^{(1)} \cdot f^{(3)}+f^{(3)} \cdot f^{(1)}+f^{(2)} \cdot f^{(2)}\right\}+\cdots\right],
\end{gathered}
$$


where $P(D)=D_{x} D_{t}-\left(e^{h y D_{y}}+e^{-h y D_{y}}-2\right)$. We collect the coefficients with respect to $\varepsilon^{i}, \forall i \geq 0$ of equation (13). The coefficient of the first term $\varepsilon^{0}$ disappears trivially, and from the coefficient $\varepsilon^{1}$ we have

$$
P(D)\left\{1 \cdot f^{(1)}+f^{(1)} \cdot 1\right\}=2 P(\partial)=2\left[\partial_{x} \partial_{y}-\left(e^{h y D_{y}}+e^{-h y D_{y}}-2\right)\right] f^{(1)}=0 .
$$

The equation (14) is a direct result of the property of the Hirota operator D [9] because $P(D)$ has an even order. The next important step in the calculation is to find solution for equation (14).

The general trend for soliton solutions is exponential, but the exponential function $f^{(1)}$ does not satisfy equation (14). Due to the nature of the q-numbers, the solution to equation (14) should have a power function for the analog of the q-discrete spatial variable. Therefore, you can choose the original solution (14) as

$$
f^{(1)}(x, y, t)=y^{\alpha} e^{\beta t+\gamma x+\eta},
$$

where, $\alpha, \beta, \eta-$ arbitrary constants.

A solution with the usual behavior of soliton and having power analogs for q-discrete variables is called a q-soliton solution. If we substitute (15) in (14), we obtain the relation between the parameters

$$
\beta \gamma=q^{\alpha}+q^{-\alpha}-2
$$

which is called the dispersion relation.

The coefficient $\varepsilon^{2}$ obtained from (13) gives the following

$$
P(D)\left\{1 \cdot f^{(2)}+f^{(2)} \cdot 1+f^{(1)} \cdot f^{(1)}\right\}=2 P(\partial) f^{(2)}+P(D)\left\{f^{(1)} \cdot f^{(1)}\right\} .
$$

That gives

$$
\begin{gathered}
{\left[D_{x} D_{t}-\left(e^{h y D_{y}}+e^{-h y D_{y}}-2\right)\right]\left\{f^{(1)}(x, y, t) \cdot f^{(1)}(x, y, t)\right\}} \\
=-2\left[\partial_{x} \partial_{t}-\left(e^{h y \partial_{y}}+e^{-h y \partial_{y}}-2\right)\right] f^{(2)}(x, y, t) .
\end{gathered}
$$

Since $f^{(1)}$ given in (14) satisfies to form (17), we can assume that all members of higher order are zero, i.e. $f^{(j)}=0, j \geq 2$. Further, as a generalization, this fact can be assumed in the derivation of the i-q-soliton solution, $f^{(j)}=0$ for all $j \geq i+1$. When $\varepsilon=1$, one-q-soliton solution is constructed by substituting equations (15) and (16) into (17) and taking into account that $f(x, y, t)=1+f^{(1)}(x, y, t)$ then

$$
V(x, y, t)=\frac{d^{2}}{d x d t} \ln f(x, y, t)=\frac{y^{\alpha} \beta \gamma e^{\beta t+\gamma x+\eta}}{\left(1+y^{\alpha} e^{\beta t+\gamma x+\eta}\right)^{2}},
$$

which is the one-q-soliton solution of the two-dimensional q-Toda lattice. The dynamics of the one-q-soliton solution is presented in Figure.

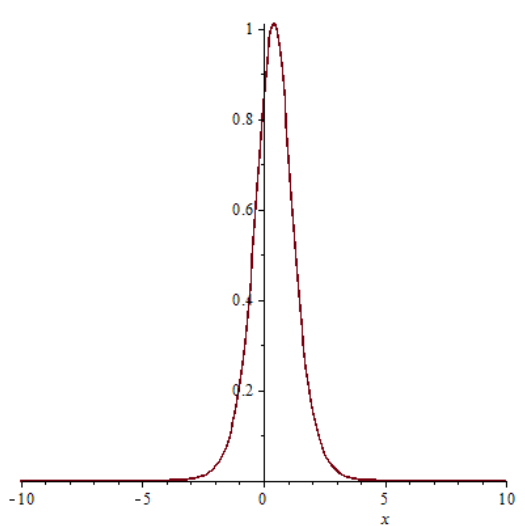

a)

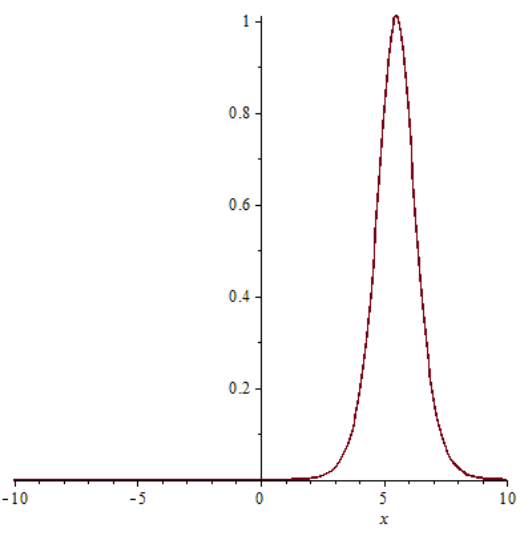

b)

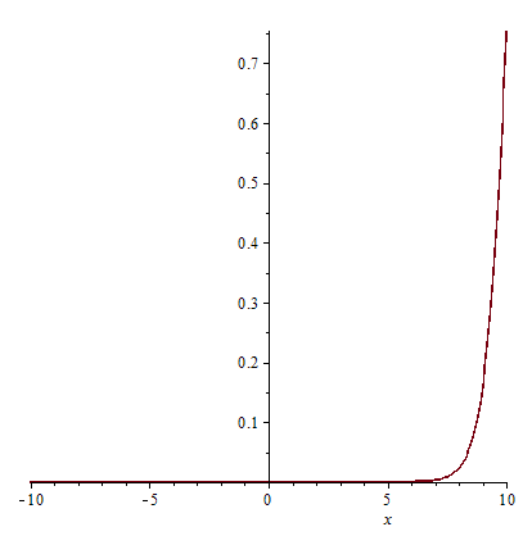

c)

Figure. Dynamics of a one-q-soliton solution for the two-dimensional q-Toda lattice with parameters: $\gamma=2, \alpha=-5, \eta=0, q=1.25$, (a) $\mathrm{t}=-5$, (b) $\mathrm{t}=0$, (c) $\mathrm{t}=5$.

Figure shows the dynamics of the obtained solution (18) depending on $t$. So with different values of $t$, the wave's shape is saved. This proves there is a soliton in a two-dimensional q-Toda lattice, which means that energy transfer is possible. The Toda lattice is unique because it has a wide range from the harmonic to the anharmonic limit and has the so-called N-soliton solutions. As presented above, soliton is a structurally unchanged solitary wave in a nonlinear environment. When interacting with each other or other disturbances, 
solitons behave like particles, therefore they are called particle-like. Due to the balance between the action of nonlinearity and dispersion, they save their structure, not collapsing in a collision.

\title{
Conclusion
}

Thus, we present the q-Toda lattice in the two-dimensional case. Using the Hirota bilinear method, we find the bilinear form for the two-dimensional q-Toda lattice and obtain the dispersion relation and the oneq-soliton solution. This algorithm can be applied to obtain $\mathrm{N}$-soliton solutions. The soliton is conserved due to the equilibrium between the action of a nonlinear environment with dispersion. In addition, the soliton behaves as a particle (particle-like): it does not collapse when interacting with each other or other disturbances while maintaining the structure and continues to move. This quality has the ability to use when transferring data or information over long distances with virtually no interference. The study of the Toda lattice in various dimensions allows one to go on to understand such complex terms as matrix models that can be used to describe different physical systems.

The article is performed as part of the financial support of the scientific and technical program (F. 0811, No. 0118RK00935) of the MES of the Republic of Kazakhstan.

\section{References}

1 Тода М. Теория нелинейных решеток / М. Тода. - М.: Высш. шк., 1984. - 262 с.

2 Vegal, L.C. Bäcklund transformation and solitonic solutions for a parametric coupled Korteweg-de Vries system / L.C. Vega1, A. Restuccia, A. Sotomayor // Journal of Physics: Conference Series. — 2014 — 490. — 012024.

3 Hirota, R. The direct method in soliton theory / Cambridge university press. - 2004. - $198 \mathrm{p}$.

4 Gardner, C.S., Method for solving the Korteweg-de Vries equation / C.S. Gardner, J.M. Greene, M.D. Kruskal, R.M. Miura // Physical Review Letters. — 1967. — 19. — P. 1095-1097.

5 Hirota, R. Exact solution of the Korteweg-de Vries equation for multiple collisions of solitons / R. Hirota // Physical Review Letters. - 1971. - 27. - P. 1192-1194.

6 Hirota, R. Exact solution of the Sine-Gordon equation for multiple collisions of solitons / R. Hirota // Journal of the Physical Society of Japan. - 1972. - 33. - P. 1459-1463.

7 Hirota, R. Exact envelope-soliton solutions of a nonlinear wave equation / R. Hirota // Journal of Mathematical Physics. 1973. - 14. - P. 805-809.

8 Мухамедина К.Т. Екікомпонентті Хирота теңдеуінің солитондық шешімдері [Soliton solutions of two-component Hirota equation] / K.T. Мухамедина, А.М. Сыздыкова, Г.Н. Шайхова // Қарағанд. ун-нің хабаршысы. Математика Сер. 2015. - 4. - P. 103-107.

9 Grammaticos, B. Multilinear operators: the natural extension of Hirota's bilinear formalism / B. Grammaticos, A. Ramani, J. Hietarinta // Physics Letters A. - 1994. - 190. — P.65-70.

10 Silindir, B. Soliton solutions of q-Toda lattice by Hirota direct method / Advances in Difference Equations. — 2012. — 121.

\author{
Б.Б. Кутум, Г.Н. Шайхова
}

\section{Екіөлшемді q-Тода тізбегінің q-солитондық шешімі}

\begin{abstract}
Тода тізбегі экспоненциалдық күш арқылы өзара әрекеттесетін, сызықтағы шексіз массалар жүйесін сипаттайтын сызықты емес эволюциялық теңдеу болып табылады. Авторлар q-Тода тізбегінің екіөлшемді кеңістіктегі солитондық шешімін құрастыруды талдады. Мақсатқа қолжеткізу үшін қозғалыс теңдеуі алынып, Хирота полиномы ретінде жазылған бисызықты түрге келтіру үшін сызықты емес теңдеуді тәуелді айнымалыны түрлендіру қолданды. Интегралданатын сызықты емес эволюциялық теңдеулердің көп солитонды шешімдерін құрастырудың тиімді әдістерінің бірі ретінде берілген әдісті көптеген теңдеулерге, олардың ішінде сызықты емес дифференциал, сызықты емес дифференциал-айырымдық теңдеулерге қолдануға болады. Хирота әдісін қолдана отырып, екіөлшемді q-Тода тізбегінің бисызықты түрі алынып, оның негізінде q-солитондық шешімі есептелді. Екіөлшемді q-Тода тізбегінің q-солитондық шешімнің динамикасы ұсынылды. Атап айтқанда, солитон сызықты емес орта мен дисперсия арасындағы әрекетінің тепе-теңдігі арқасында сақталады. Сонымен қатар солитон өзін бөлшек ретінде ұстайды: бір-бірімен немесе басқа ауытқулармен өзара әрекеттесу кезінде қирамай, құрылымын сақтап, қозғалысын жалғастырады. Осындай қасиетті мәліметті немесе ақпаратты алысқа дерлік кедергісіз жіберу кезінде қолдануға мүмкіндік туғызады. Бұдан басқа, Тода тізбегін және оған түрлі өлшемділіктегі әртүрлі әдістердің қолдануын зерттеу
\end{abstract}


әркелкі физикалық жүйелерді сипаттау мақсатында қолдануға болатын, матрицалық модельдер сияқты күрделі терминдерді түсінуге мүмкіндік туғызады.

Кілт сөздер: дисперсия, солитон, Тода тізбегі, бисызықты форма, Хирота әдісі.

\author{
Б.Б. Кутум, Г.Н. Шайхова
}

\title{
Q-солитонное решение двумерной цепочки q-Тоды
}

\begin{abstract}
Цепочка Тоды является нелинейным эволюционным уравнением, описывающим бесконечную систему масс на линии, которые взаимодействуют через экспоненциальную силу. В работе проведен анализ построения солитонного решения цепочки q-Тоды в двумерном пространстве. Для этой цели взято уравнение движения и использовано преобразование зависимой переменной для преобразования нелинейного уравнения в билинейную форму, которая записана как полином оператора Хироты. Как один из наиболее эффективных методов построения многосолитонных решений интегрируемых нелинейных эволюционных уравнений, данный метод применим к широкому классу уравнений, включая нелинейные дифференциальные, нелинейные дифференциально-разностные уравнения. Применяя метод Хироты, была получена билинейная форма для двумерной цепочки q-Тоды на основе, которой найдено q-солитонное решение. Представлена динамика q-солитонного решения двумерной цепочки q-Тоды. Отметим, что солитон сохраняется благодаря равновесию между действием нелинейной среды с дисперсией. Помимо этого солитон ведет себя как частица: не разрушается при взаимодействии друг с другом или другими возмущениями, при этом сохраняет структуру и продолжает движение. Такое качество имеет возможность использования при передаче данных или информации на дальние расстояния практически без помех. Кроме того, исследование цепочки Тоды и применение к ней разных методов в различных размерностях позволяет перейти к пониманию таких сложных терминов, как матричные модели, которые можно применить для описания разных физических систем.
\end{abstract}

Ключевые слова: дисперсия, солитон, цепочка Тоды, билинейная форма, метод Хироты.

\section{References}

1 Toda, M. (1984). Teoriia nelineinykh reshetok [Nonlinear lattice theory]. Moscow: Vysshaia shkola [in Russian].

2 Vegal, L.C., Restuccia, A., \& Sotomayor, A. (2014). Bäcklund transformation and solitonic solutions for a parametric coupled Korteweg-de Vries system. Journal of Physics: Conference Series, 490, 012024.

3 Hirota, R. (2004). The direct method in soliton theory. Cambridge university press.

4 Gardner, C.S., Greene, J.M., Kruskal, M.D., \& Miura, R.M. (1967). Method for solving the Korteweg-de Vries equation. Physical Review Letters, 19, 1095-1097.

5 Hirota, R. (1971). Exact solution of the Korteweg-de Vries equation for multiple collisions of solitons. Physical Review Letters, 27, 1192-1194.

6 Hirota, R. (1972). Exact solution of the Sine-Gordon equation for multiple collisions of solitons. Journal of the Physical Society of Japan, 33, 1459-1463.

7 Hirota, R. (1973). Exact envelope-soliton solutions of a nonlinear wave equation. Journal of Mathematical Physics, 14, 805809.

8 Mukhanmedina, K.T., Syzdykova, A.M., \& Shaikhova, G.N. (2015). Ekikomponentti Hirota tendeuinin solitondyk sheshimderi [Soliton solutions of two-component Hirota equation]. Karahandy universitetinin khabarshysy. Matematika Seriiasy Bulletin of the Karaganda University. Series Mathematics, 4, 103-107 [in Kazakh].

9 Grammaticos, B., Ramani, A., \& Hietarinta J. (1994). Multilinear operators: the natural extension of Hirota's bilinear formalism. Physics Letters A, 190, 65-70.

10 Silindir, B. (2012). Soliton solutions of q-Toda lattice by Hirota direct method. Advances in Difference Equations, 121. 


\title{
ЖЫЛУ ФИЗИКАСЫ ЖӘНЕ ТЕОРИЯЛЫҚ ЖЫЛУ ТЕХНИКАСЫ ТЕПЛОФИЗИКА И ТЕОРЕТИЧЕСКАЯ ТЕПЛОТЕХНИКА THERMOPHYSICS AND THEORETICAL THERMOENGINEERING
}

DOI $10.31489 / 2019 \mathrm{Ph} 3 / 27-33$

UDC 620.9:662.6; 621.1

\author{
A.D. Mekhtiyev, P.M. Kim, V.V. Yugay, A.D. Alkina \\ Karaganda State Technical University, Kazakhstan \\ (E-mail: Barton.kz@mail.ru)
}

\section{Electrovacuum heating elements}

\begin{abstract}
Improving the efficiency of heat supply systems for buildings and structures in the current trends in the global development of energy saving cannot be fully realized without the introduction of high-tech and low-energyintensive electrical equipment. The heat supply of remote objects for various purposes is accompanied by significant losses, since the coolant has to cover considerable distances, in some cases the connection of the object to the heating plant is impossible due to technical problems or considerable material costs for the installation of pipelines. One solution could be the introduction of a low-pressure steam electric heater. This is a new generation electric heater with a fundamentally new design of the heating element. It combines the efficiency of an electric spiral and the comfortable warmth of a traditional heating radiator.
\end{abstract}

Keywords: radiator, electric heater, energy saving, heating system, heating device, heating.

Throughout the developmental stages of his development, man sought ways to heat his home. It all started with a fire, then the stoves and fireplaces were invented. With the development of technology, previous methods were replaced by autonomous heating systems with boilers operating on various types of fuel and thermal power plants capable of heating cities. But despite the presence of a centralized heating system, a person is not always satisfied with the ambient air temperature in a residential area, such a situation may occur during the interseasonal heating time when the outdoor temperature is still cool and the central heating system is not functioning or has already ceased to function due to the end your season work. A similar situation arises in the southern countries, where there is practically no cold winter and snow, but there are small periods of time when a heat source is needed to heat the dwelling. To solve this problem, you can use a solid fuel and gas stove, but it is not always acceptable for urban conditions besides the fire hazard of a heat source with open fire, it also produces harmful emissions of exhaust gases in the course of its work, which harm the environment of the city and create local areas of concentration of flue gas. The search for the most ecologically clean source of heat prompted engineers to use electric current and create an electric heater, a kind of autonomously working heat source connected to the electrical network. Compact thermal device is capable of producing enough warm to heat a home.In the 30s of the last century in Geneva, the French engineer Jacques Noir [1] developed and launched into production an electric heater, the basis of its design was an electric spiral, which was blown by the air flow created by a fan. Subsequently, he created his own company «Noir». At the same time, oil radiators were developed, the heating element was immersed in oil, placed in a sealed metal case from which heat is transferred to the surrounding air. In the process of heating, the oil transfers the resulting heat to the environment. Each type of heat equipment has certain disadvantages and advantages that have already been described many times in the literature, as well as electric heaters have come a long way to improve and modernize their design [2]. In 1972, the company «Noir» products came to the market with electric heaters equipped with a thermostat, it was possible to regulate the temperature of the supplied air. In 1988, the company «Noir» created 
a convector, which was later taken as a basis by many manufacturers. The production of a convection-type heater has opened up new possibilities for heating devices: safety, operation of the device without noise, energy saving. In 2000, a new type of heater called the «Kalida», equipped with a climate control system, entered the market. Currently in the world there are a huge number of different types of heaters and manufacturers of this electrical equipment. The analysis of world production of electric heaters is very significant and is presented by various companies in Europe, Asia and America, for example: De'Longhi, General Climate, Polaris, EWT, Hansa, Timberk, Supra Wika, Fluke, Noir, Hyundai, Resanta, NOVEL, ZASS, Kaiser, Ballu, Siemens, EVUB [3]. Electrical oil with a spiral heating element, convectors, split-systems, as well as infrared heaters are produced. At the moment, the export of electric heaters in Kazakhstan is $100 \%$, the vast majority is collected in factories in China. Our task is to develop a new generation electric heater equipped with all modern electronic monitoring and control systems, which will make it possible to achieve maximum comfort of use and efficiency of the thermal device.

We have developed a low-pressure energy-saving steam electric heater (LSEH), which can be a substitute for a traditional oil cooler, as well as to compete with existing electric heaters. LSEH combines the advantages of electric spiral, converters and oily electric heaters into a single whole. For example, oily electric heater contains oil that is dangerous in the fire relationship, it heats up for a long time, the metal body heats up strongly, and the oil is subject to degradation. In addition to the thermostat, more expensive branded models have a timer and protection that turns it off from the network when tipping to the floor, which makes its use more convenient and safer. Heaters with an electric helix also have several disadvantages, for example, emit unpleasant odors when burning dust and create noise during their work. There is also an analogue of LSEH developed by VEST, but which has a number of serious differences, its cost is several times higher than the electric heater proposed by us, so it cannot be considered in future as a competitor in the market [4].

After analyzing the sources [5], we developed a LSEH, which does not have the above disadvantages of the above-mentioned electric heaters, has high efficiency and creates comfortable heat. This is a fully automated electric heater with the «Climate Control» system and the possibility of coordination with the «Smart Home» system; it is controlled by using a remote control or a smartphone. The achieved technical indicators of the electric heater make it possible to ensure its service life for more than 20 years with a constant efficiency of $90 \%$.

We have developed and created an experimental laboratory sample of LSEH, consisting of separate sections with a capacity of from 50 to 100 watts. The block-modular layout of the electric heater allows the owner to change its power, if it is necessary, independently, without resorting to the services of skilled workers. Sections are connected in parallel using electrical connections. The LSEH section is made of duralumin alloy, inside which is placed a vacuum electric heater. One section can effectively heat up to $3 \mathrm{~m}^{2}$ of living space at a ceiling height of 2.5 meters. The appearance of the prototype laboratory sample and the device of the electrovacuum heater is shown in Figure 1. The LSEH can be floor mounted or mounted on the wall, like a classic radiator, only instead of pipes you need to connect an electrical wire to it, which simplifies its installation [6].
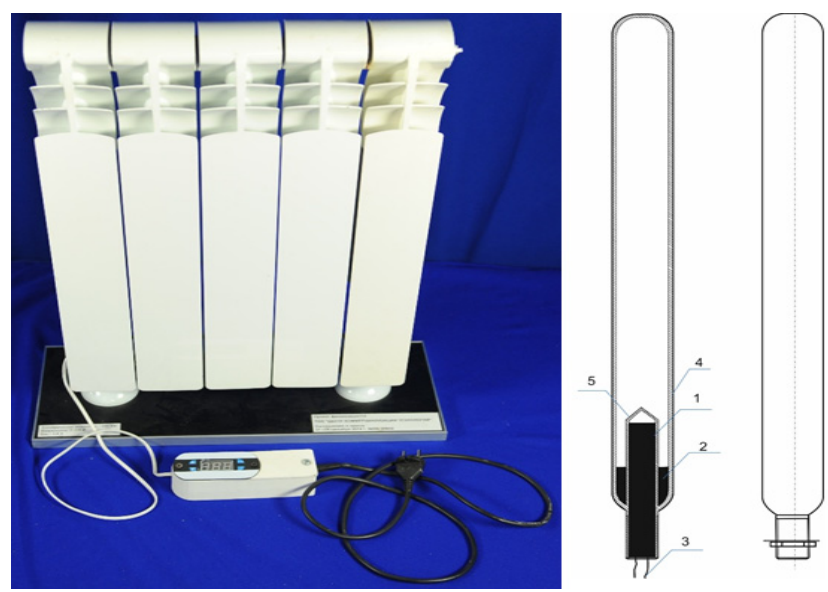

Figure 1. The appearance of the experimental laboratory sample and the device of the electrovacuum heater LSEH 
The basis of the LSEH is an electrovacuum heater, which operates as follows: an electric spiral heater 1 provides for rapid heating of the heat-transfer fluid 2 (distilled water); electric current is supplied to the coil by means of electrical wires 3 . When the heat-carrier evaporates, the steam reaches the upper part of the body 4 , where it gives off heat received from the heater. Cooling off steam condenses and flows along the walls of the body to the bottom again heats up and evaporates. The principle of its operation is based on the well-known effect of the phase transition of a heat pipe. The electric heating element is placed in the housing 5 and does not come into contact with the coolant [7]. The recommended pressure inside the electrovacuum heater should be within $4.053 \mathrm{kPa}(0.04$ bar). Heat particles move inside the body at the speed of sound due to which the LSEH section weighing about 230 grams is heated to $700{ }^{\circ} \mathrm{C}$ in less than 5 minutes, unlike the traditional oily electric heater more than 5 times faster. But there is one problem in the design that had to be solved in order to achieve reliable performance of the LSEH, this is to ensure high tightness of the body of the electrovacuum heating element, since when the pressure rises above $0.1 \mathrm{Atm}$, the effect of high-grade heating is lost, there were also problems with the set of the required temperature. The principle of operation is discussed in detail in the source [8], and also the novelty of the electrovacuum heating element is given.

During the work on the design of LSEH, we have developed a 3D model (Fig. 2). 3D model allows to execute drawings for its production, as well as to learn more about the device electric heater [9].

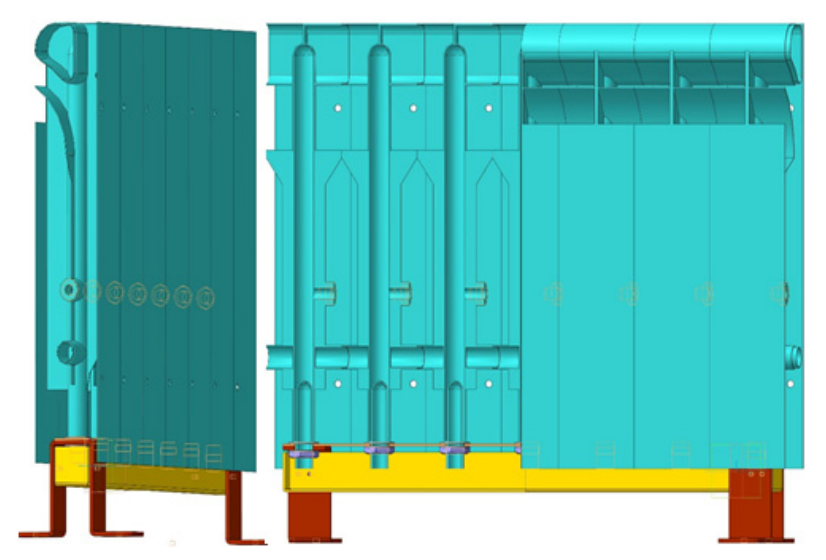

Figure 2. 3D model of LSEH

In the process of creating LSEH, we carried out a series of laboratory experiments aimed at improving the design of an electrovacuum heater, which were made in the form of copper tubes with diameter of 20, 28, 32, weight from 270 to 530 grams, length from 250 to $450 \mathrm{~mm}$, heater power $-60,80$ and 100 watts. The pressure inside the tube is $4-10 \mathrm{kPa}(0.04-0.1 \mathrm{~atm})$. Temperature is $0{ }^{\circ} \mathrm{C}$. In total, we manufactured and tested 40 electric vacuum heaters. Some results are presented in the dependency graphs in Figures 4 and 5. Temperature was measured using a Fluke 51 contact thermometer with laboratory accuracy $(0.05 \%+$ $\left.0.3^{\circ} \mathrm{C}\right)$ and a measurement limit of up to $900^{\circ} \mathrm{C}\left(1600^{\circ} \mathrm{F}\right)$. Vacuum pump DUO 6/M SERIES PFEIFFER VACUUM with an integrated vacuum meter was used to create the vacuum [10].

The required number of repetitions of experiments [11] is determined on the basis of the coefficient Kvar and the required degree of accuracy.

The value of the coefficient of variation is determined by the formula:

$$
K_{\text {var }}=\frac{100 \cdot \delta}{\chi}, \%
$$

where $\delta$ - mean square deviation;

$\chi$ - arithmetic average.

The value of the mean square deviationis calculated by the formula:

$$
\delta=\sqrt{\frac{\sum \delta_{i}^{2}}{N-n}}
$$

where $\boldsymbol{\delta}_{i}$ - deviations of individual results from group means;

$\mathrm{N}$ - the total number of experiments;

$\mathrm{n}$ - the number of experimental groups [12]. 
To establish the required number of experiments a valid value of $K_{a d d}$ in percent is given. Knowing the coefficient of variation $\mathrm{K}_{\mathrm{var}}$ for a given test method, it is possible with a reliability of 0.95 to determine the required number of experiments. According to the results of numerous experimental data, $\mathrm{K}_{\mathrm{add}}=12 \%$ is taken $\left(\mathrm{K}_{\mathrm{var}}=11.5 \%\right)$. This coefficient corresponds to (with a confidence probability of 0.95$)$ the required number of experiments equal to 4 . During the processing of the exertional data, data processing using the means of the Microsoft Excel spreadsheet processor, quadratic interpolation of the function (solid line) and the rms (root mean square) approximation (dashed line) were used, as well as performed regression analysis.

Figure 3 shows a plot of temperature change versus heating time for tubes with volume of 10 and $15 \mathrm{ml}$. The tube of the electrovacuum heater with the parameters copper $-28 \mathrm{~mm}$ in diameter, weight $-355 \mathrm{~g}$, length $-310 \mathrm{~mm}$, heater power $-80 \mathrm{~W}$ was investigated. The volume of coolant is 10 and $15 \mathrm{ml}$. The pressure inside the tube is $5.066 \mathrm{kPa}(0.05 \mathrm{~atm})$.

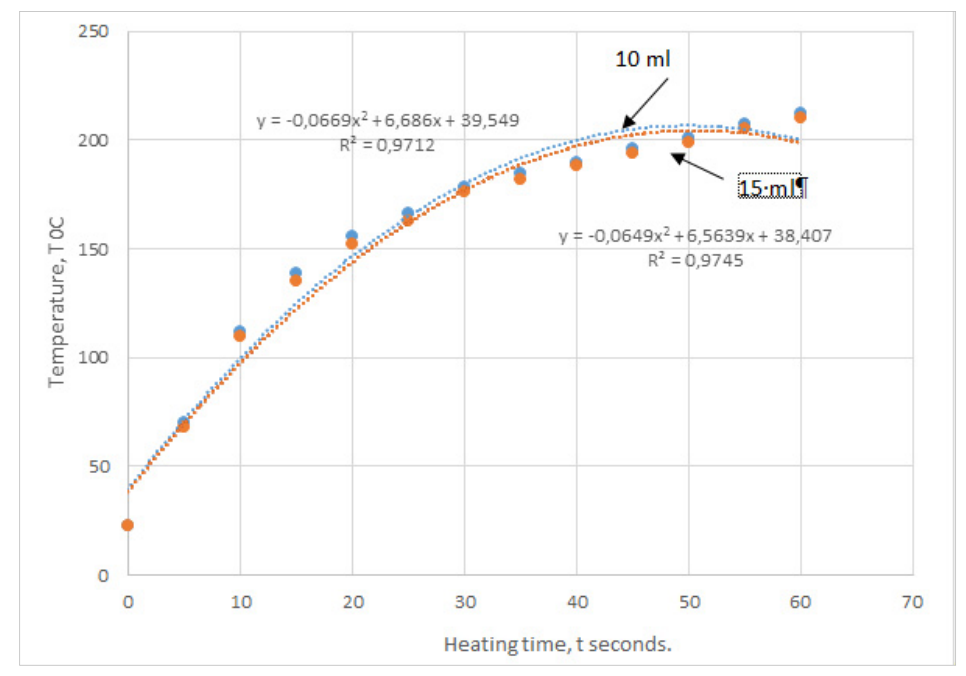

Figure 3. Graph of temperature change versus heating time for tubes with a volume of 10 and $15 \mathrm{ml}$

Figure 4 shows a plot of temperature versus coolant volume from 5 to $15 \mathrm{ml}$. The tube of an electrovacuum heater with a tube with parameters copper $20 \mathrm{~mm}$ in diameter, weight $-368 \mathrm{~g}$, length $305 \mathrm{~mm}$, heater power $-80 \mathrm{~W}$ was investigated. The volume of coolant is 10 and $15 \mathrm{ml}$. The pressure inside the tube is $4,053 \mathrm{kPa}(0.04 \mathrm{~atm})$. Presumably, in the process of switching to a pressure of $0.01 \mathrm{~atm}$ $(1.01 \mathrm{kPa})$, the efficiency of the electrovacuum heater, as well as the heat pipe, can be increased by $15-20 \%$, because the friction energy losses in a more discharged atmosphere decrease, the transmission rate can reach sound. If the pressure in the heat pipe is lower, then the heat transfer process is more efficient and the efficiency is higher. In the process of increasing the pressure in the internal cavity of an electrovacuum heater (above $0.1 \mathrm{~atm}$ ), the effect of high-grade heating is completely lost and there are problems with a set of the required temperature.

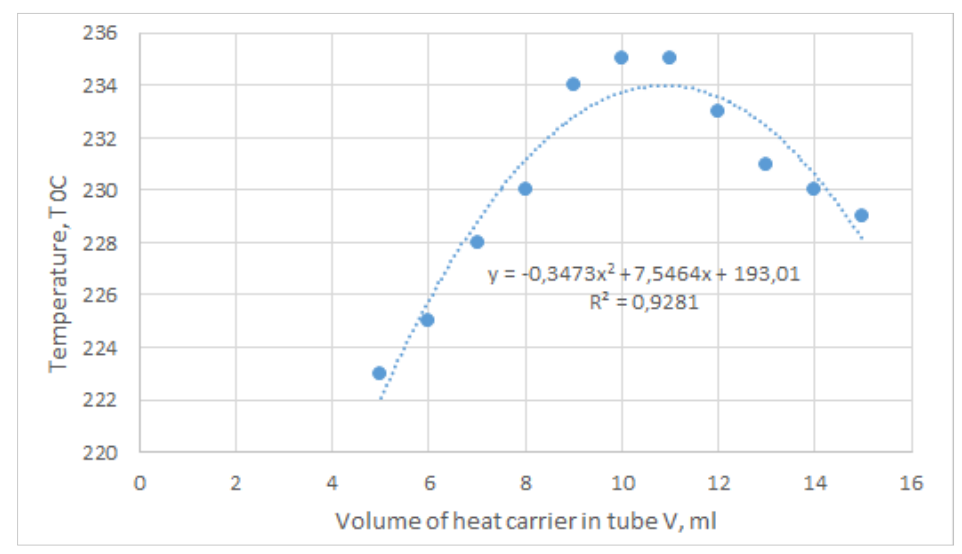

Figure 4. A plot of temperature change versus coolant volume from 5 to $15 \mathrm{ml}$ 
We have carried out experiments related to the determination of the mass of an $80 \mathrm{~W}$ electric vacuum heater. The volume of coolant is 10 and $15 \mathrm{ml}$. The pressure inside the tube is $5.066 \mathrm{kPa}(0.05 \mathrm{~atm})$. As the mass increases, the surface temperature of the heater decreases. The tests were carried out with 5 samples of different mass when heated from 1300 to 2160 with a mass of, respectively, from 230 to 530 grams. The dependence of the temperature change of the surface of the housing of the electrovacuum heater on its mass is established, the graph is shown in Figure 5. The LSEH has automatic power adjustment depending on the ambient temperature in the room, therefore, if necessary, the electrovacuum heater has a significant dynamic range margin for adjustment.

It should be noted that modern electric heaters have low maintainability, this leads to the fact that the consumer is not able to perform repairs on his own and is forced to contact specialized organizations that perform repairs, on the one hand it's right that the manufacturer excludes the possibility of self-repair at home, but workshops cannot always help in the repair, a couple just do not have the necessary spare parts. Sections LSEH have a unified design and allow you to repair by yourself.

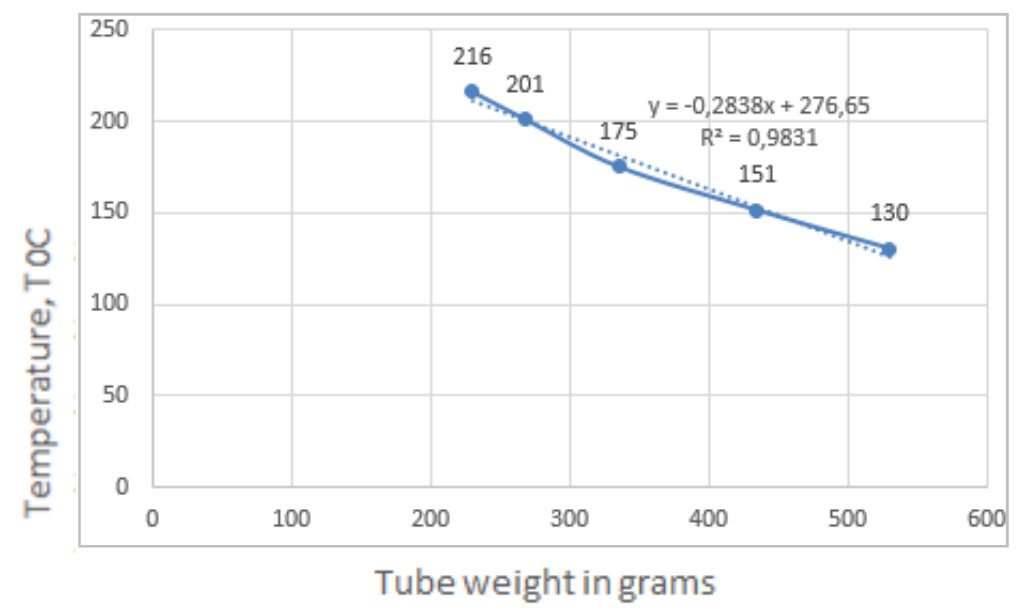

Figure 5. Dependence of the surface temperature of the case of an electrovacuum heater on its mass

A low-pressure energy-saving steam electric heater is an economical replacement for a traditional oil radiator; it can compete with existing electric heaters. The technological advantage is the high efficiency of heat transfer inside the system without loss. The main economic advantage of LSEH is lower power consumption; it is up to 1.3 times less than an oily electric heater, high reliability and a long service life. LSEH is absolutely safe in terms of an explosion or a fire in the event of a leak or falling onto the floor. Water is used in the place of expensive synthetic oil, which significantly reduces the cost and facilitates the design of the electric heater. Low material costs for installation and operation of the heating system are not achievable by competitors, $100 \%$ automation with the possibility of coordination with the «Smart Home» system. The use of LSEH technology can have a multiplier effect for creating heating radiators with a liquid heat carrier; this will allow reducing their metal consumption and cost, without loss of consumer qualities. There is an opportunity to use our technology in systems «warm floor».

\section{Список литература}

1 Сайт журнала «История бытовой техники» [Электронный ресурс]. — Режим доступа: http://tehnikaland.ru /klimaticheskaya-tehnika/istoriya-izobreteniya-obogrevatelya.html

2 Сайт журнала «ОВІ» [Электронный ресурс]. — Режим доступа: https://diy.obi.ru/articles/ obogrevateli-plusi-i-minysi19964/

3 Козлов С.В. Современные высокоэффективные автономные энергосберегающие системы отопления / С.В. Козлов // Новости теплоснабжения - 2007. - № 8. - С. 84-86.

4 Сайт журнала «Onliner» [Электронный ресурс]. — Режим доступа: https://people.onliner.by/2015/09/25/heater

5 Сайт журнала «Электронагреватели парокаптельного типа» [Электронный ресурс]. — Режим доступа: http://vestkz.ru/opisanie.htm

6 Температуры касаемых поверхностей. Эргономические данные для установления предельных величин горячих поверхностей: ГОСТ 51337-99. - М., 2000 - 16 с. 
7 Братенков В.Н. Теплоснабжение малых населенных пунктов / В.Н. Братенков, П.А. Хаванов, Л.Я. Вэскер. - М.: Стройиздат, 1988. - 223 с.

8 Дмитриев А.Н. Энергосбережение в реконструируемых зданиях / А.Н. Дмитриев, П.В. Монастырев, С.Б. Сборщиков. — М.: Изд-во АСВ, 2008. - 208 с.

9 Радиатор отопления: Патент на полезную модель № 2816. - Зарегистрирован в Государственном реестре полезных моделей Республики Казахстан, 24.04.2018 г.

10 Радиатор отопления: Патент на изобретение № 32156 - Зарегистрирован в Государственном реестре изобретении Республики Казахстан, 16.05.2017 г.

11 Аметистов Е. В. Основы теории теплообмена / Е.В. Аметистов. - М.: Изд. МЭИ, 2000. - 242 с.

12 Безродный М.К. Процессы переноса в двухфазных термосифонных системах: моногр. / М.К. Безродный, И.Л. Пиоро, Т.О. Костюк. - Киев: Факт, 2003. - С. 55-57.

\title{
А.Д. Мехтиев, П.М. Ким, В.В. Югай, А.Д. Алькина Электрвакуум жылыту элементтері
}

\begin{abstract}
Ғимараттар мен құрылыстардың жылу мен жабдықтау жүйелерінің энергия үнемдеудің жаһандық дамуының ағымдағы үрдістеріндегі тиімділігін жоғарылату жоғары технологиялық және төменқуатты тұтынатын электржабдықтарын енгізбестен толығымен іске асырыла алмайды. Әртүрлі мақсаттар үшін қашықтағы объектілерді жылумен жабдықтау маңызды шығындармен қатар жүреді, себебі салқындатқыш қашықтықты айтарлықтай қамтуы тиіс, ал кейбір жағдайларда құбырларды орнатуға техникалық қиындықтар немесе елеулі материалдық шығындар салдарынан нысанды жылыту қондырғысы қосылмайды. Бір шешім ретінде төменқысымды буэлектрлі жылытқышты енгізу болып табылады. Бұл қыздыру элементінің түбегейлі жаңа дизайны мен жаңа буын электржылытқышы. Ол электрлік спиралдың тиімділігін және дәстүрлі жылурадиаторының ыңғайлы жылуын біріктіреді.
\end{abstract}

Кілm сөздер: радиатор, электржылытқышы, энергияүнемдеу, жылыту жүйесі, жылыту құрылғысы, жылыту.

\section{А.Д. Мехтиев, П.М. Ким, В.В. Югай, А.Д. Алькина Электровакуумные нагревательные элементы}

\begin{abstract}
Повышение эффективности систем теплоснабжения зданий и сооружений в современных тенденциях общемирового развития энергосбережения не может быть реализовано в полной мере без внедрения высокотехнологичного и низкоэнергоемкого электрооборудования. Теплоснабжение удаленных объектов различного назначения сопровождается значительными потерями, так как теплоносителю приходиться преодолевать значительные расстояния, в некоторых случаях подключение объекта к теплоцентрали невозможно в силу технических проблем или значительных материальных затрат на монтаж трубопроводов. Одним из решений может быть внедрение парового электрообогревателя низкого давления. Это электрообогреватель нового поколения с принципиально новой конструкцией нагревательного элемента. В нем сочетаются эффективность электрической спирали и комфортное тепло традиционного радиатора отопления.
\end{abstract}

Ключевые слова: радиатор, электрообогреватель, энергосбережение, система теплоснабжения, тепловой прибор, отопление.

\section{References}

1 Sait zhurnala «Istoriia bytovoi tekhniki» [Site of journal «History of household appliances»]. tehnikaland.ru. Retrieved from http://tehnikaland.ru/klimaticheskaya-tehnika/istoriya-izobreteniya-obogrevatelya.html [in Russian].

2 Sait zhurnala «OBI»[Site of journal «OBI»]. diy.obi.ru. Retrieved from https://diy.obi.ru/articles/obogrevateli-plusi-iminysi-19964/ [in Russian].

3 Kozlov, S.V. (2007). Sovremennye vysokoeffektivnye avtonomnye enerhosberehaiushchie sistemy otopleniia [Modern highefficiency Autonomous energy-saving heating systems]. Novosti teplosnabzheniia - News of heat supply 8, 84-86 [in Russian].

4 Sait zhurnala «Onliner» [Site of journal «Onliner»]. people.onliner.by. Retrieved from https://people.onliner.by /2015/09/25/heater [in Russian].

5 Sait zhurnala «Elektronahrevateli parokaptelnoho tipa» [Site of journal «Electric heaters of steam-drop type»]. vestkz.ru. Retrieved from http://vestkz.ru/opisanie.htm [in Russian]. 
6 Temperatury kasaemykh poverkhnostei. Erhonomicheskie dannye dlia ustanovleniia predelnykh velichin horiachikh poverkhnostei (2000) [The temperatures of the surfaces to be touched. Ergonomic data for setting the limit values of hot surfaces]. HOST 51337-99. Moscow [in Russian].

7 Bratenkov, V.N., Havanov, P.A., \& Vesker, L.Ya. (1988). Teplosnabzhenie malykh naselennykh punktov [Heat supply to small settlements]. Moscow: Stroiizdat [in Russian].

8 Dmitriev, A.N., Monastyrev, P.V., \& Sborshchikov, S.B. (2008). Enerhosberezhenie v rekonstruiruemykh zdaniiakh [Energy savings in reconstructed buildings]. Moscow: Izdatelstvo ASV [in Russian].

9 Radiator otopleniia [Heating radiator]. (2018). Patent na poleznuyu model No. 2816 - Zarehistrirovan v Hosudarstvennom reestre poleznykh modelei Respubliki Kazakhstan, 24.04.2018 [in Russian].

10 Radiator otopleniia [Heating radiator]. (2018). Patent na izobretenie No. 32156 -Zarehistrirovan v Hosudarstvennom reestre izobretenii Respubliki Kazahstan, 16.05.2017 [in Russian].

11 Ametistov, E.V. (2000). Osnovy teorii teploobmena [Fundamentals of heat transfer theory]. Moscow.: Izdatelstvo MEI [in Russian].

12 Bezrodnyi, M.K. (2003). Protsessy perenosa v dvukhfaznykh termosifonnykh sistemakh [Transfer processes in two-phase thermosyphon systems]. Kiev: Fakt [in Russian]. 